\title{
Teaching of English Using Online Tools During Pandemic
}

\author{
Mijo Rexly and P. Sathya \\ Department of English, Holy Cross College (Autonomous), Nagercoil, India
}

\begin{abstract}
The Covid-19 pandemic has affected all the elements of the global citizens including educational institutions. Government announced to close all the education institutions including schools, colleges and universities to reduce the spread of Covid-19. The face to face language teaching has shifted to online teaching. Online teaching encourages the learners participate actively in the learning process. Teachers use innovative technology in their teaching process by altering the teaching methods. The various online applications and testing tools have enhanced the LSRW skills of the learners. It also motivates and enhances the learners' interest in learning in a non-threatening atmosphere, wherein learning has become less stressful. Teachers use various online tools and platforms during the Covid-19 pandemic in their teaching which supports learning without leaving the values of traditional learning. The game-based application is a new approach to education which has motivated the learners and also has created a positive change among the learners. This paper focuses on online teaching tools, applications and platforms which enhance learning during the Covid-19 pandemic.
\end{abstract}

\section{KEY WORDS: COVID-19, TECHNOLOGY, ONLINE TEACHING, INNOVATIVE TECHNOLOGY, ONLINE TOOLS.}

\section{INTRODUCTION}

Language is a source of communication through which we share our ideas, feelings, views and thoughts with others. English is the widely used language in international trade, mass entertainment, communication, journalism, tourism and scientific publications. Most of the native and non-native speakers of English use English as their mode of communication in the trade business. English is used as the de facto language in the field of science and technology. English is also used by some world organizations such as UNO, WHO, UNESCO, UNICEF, etc. The Covid-19 disease has affected all the elements of the global citizens and government announced to close all the educational institutions including schools, colleges and universities to reduce the spread of Covid-19. The face to face language teaching has shifted to online teaching. Learning through the implementation of technology has increased in the recent modern world. Technology is a best tool for learners to learn and it is an effective tool for them which also promoted critical thinking and problem solving.

Biosc Biotech Res Comm P-ISSN: 0974-6455 E-ISSN: 2321-4007
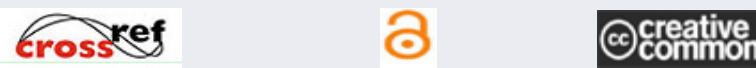

Identifiers and Pagination

Article Information

Year: 2021 Vol: 14 No (8) Special Issue

Received: $10^{\text {th }}$ May 2021

Pages: 121-129

Accepted after revision: $14^{\text {th }}$ July 2021

This is an open access article under Creative

Commons License Attribn 4.0 Intl (CC-BY).

DOI: $h t t p: / / d x$.doi.org/10.21786/bbrc/14.8.29
The different kinds of technological devices were used to enhance listening, reading and writing skills are through power point, game-based applications and audio visual devices. The audio visual aids used in teaching English help the learners to learn the language more effectively. Listening, speaking, reading and writing are the essential skills for learning any language. These skills are learnt using various applications during the Covid-19 pandemic. The game-based application used by the teachers in their teaching made the learners to learn with interest and fun. It develops interest and increases motivation among the learners. Most of teachers have a positive attitude towards online teaching during the Covid-19 pandemic which enhances their interest in learning. During the Covid-19 pandemic several arrangements has made for the learners by the Ministry of Human Resources Development (MHRD) including online portals and educational channels on television and radio for learners to continue learning. Social media tools such as Google Meet, Zoom, YouTube, Facebook, etc. are used for online teaching and learning. Teachers face many difficulties and challenges in online teaching due to lack of experience, knowledge and interest.

Impact of Covid-19 in Education System: The spread of corona virus disease and global lockdown has affected all elements of the global citizens including the educational system. The government decided to close educational institutions temporarily to reduce the spread of Covid-19. Schools were shutdown in response to the pandemic and it affected approximately 825 million learners. According to 
the United Nations International Children Fund (UNICEF), 91\% of the learners were affected worldwide and 1.6 billion learners were unable to attend schools due to the lockdown during the Covid-19 pandemic. UNESCO has come up with distance learning programmes, open educational applications and various social platforms for the learners to reduce break in their learning. The Covid-19 pandemic has created opportunities for the learners to come out of the classroom teaching model to digital mode of learning. Using digital tools in language teaching has few benefits such as increase teaching efficiency and quality, using different teaching styles, increase learners motivation and interest. Teachers face many challenges in adapting to online teaching and in the development of learners learning. Through online learning, learners can be independent and innovative in the learning process and also equips learners with knowledge and provides more experience.

Communication Skills: Communication skills comprises of Listening, Speaking, Reading and Writing in which listening and reading are regarded as passive skills, on the other hand speaking and writing are active skills. These skills help an individual to comprehend, construct and use the language effectively. Listening is an active process and the learner can acquire a language by listening. Speaking is a productive skill which enhances the learners' fluency and makes them to learn in a better way. Reading helps to enrich their vocabulary and it also provides knowledge and understanding. In the modern era, written messages play a vital role than face to face conversation. Writing helps learners to develop imaginative and critical thinking abilities.

Listening Skill: Listening skill is the basic and essential skill for language learning. According to Hedge (2000) listening has an important role in day to day life and people are engaged in communication whereas 9 percent spent in writing, 16 percent spent on reading, 30 percent spent on speaking and 45 percent spent on listening which shows the importance of listening in the communication process. Listening skill can be developed through systematic teaching. The teachers should create opportunities for the learners to practice listening, by engaging them into activities. The three phases of listening activities are pre-listening, while-listening and post-listening which helps the teachers and learners to involve themselves in listening activities. The sub skill of listening skill includes listening for gist, listening for specific information and listening for detail. Listening through audio allows the learners to understand the spoken language. Some of the listening tools used in the classroom are tape recorders, TV and radio broadcasting, CD players, computers, etc.

Speaking Skill: Among the four key language skills speaking is considered as the most important skill in learning a language. According to Bueno, Madrid and Mclaren (2006), Speaking is one of the most difficult skills, language learners have to face because speakers have to produce sentences at the moment. There are three kinds of speaking situations such as interactive, partially-interactive and non-interactive. Interactive speaking situation includes telephone calls and face-toface conversations. In the interactive speaking, there will be a chance for repetition and clarification. Interactive speaking situation are more useful for both the speaker and the listener as they can understand the speech without difficulty. In partially interactive situation, the speaker gives speech to the live audience and there will be no interaction during the speech. The speaker can directly see the audience and can also judge from their facial expressions and gestures whether the participants have understood the content. The audience can clarify their doubts through the question and answer session which takes place at the end of the presentation. In non-interactive speaking situation, there will not be any interaction and so the speakers have to just record their speech for a radio broadcast. Internet voice chatting and artificial intelligence are also used to enhance the speaking skills of the learners.

Reading Skill: Reading is an interactive process in which readers construct a meaningful representation of a text using effective reading. Grabe (1991) defined reading as an interactive process between readers and texts. There are two kinds of reading, namely loud reading and silent reading. The loud reading is closer to pronunciation than to comprehension whereas silent reading varies from person to person. All the important study skills require quick, efficient and imaginative reading and this is possible in silent reading rather than in loud reading. The main techniques of reading are skimming where reading is done to get the gist of the text, scanning where reading is done to look for specific piece of information, extensive reading is done for pleasure and intensive reading is done in detail.

Skimming is a technique that involves quick glancing through a text in order to understand its general content. Scanning involves glancing rapidly through the text to find out some specific piece of information. Intensive reading or reading for accuracy involves approaching a text under the close guidance of a teacher or through a task that forces the student to pay attention to the text. An intensive reading lesson is primarily concerned with developing reading strategies such as judgement, reasoning, interpretation, appreciation, etc. Extensive reading plays a vital role in the learning of a second or foreign language. Some of the technological devices used in enhancing reading skills among the learners are E-newspapers, multimedia softwares, E-dictionaries, E-books, etc.

Writing Skill: Writing skill is not a natural process it is pre-planned, non-repetitive, spelled, grammatically checked and punctuated work. Writing skill develop the learners to express their ideas and seek others guidance to develop it for better outcome. Good writing skill allows the individual to communicate the message with clarity. The four important skills involved in writing are mechanical skill, grammatical skill, judgmental skill and discourse skill. Ong'ondo (2001) has classified writing into two categories such as functional and creative. 
Functional writing includes writing of notices, report, letters, speeches and book reviews. Creative writing depends upon the capabilities of telling or retelling the parts of information in descriptive or narrative way which is used to change the information into a new text. Teachers can use E-mails, internet text chatting, WhatsApp, and other social media platforms to enhance the writing skills of the learners.

Impact of Social Media in Education: Social media play an indispensable role in the development of second language learning by providing a wide range of authentic materials. It has become a common tool that is used on academic institutions by everyone to share academic works, research findings, book reviews and to communicate with their peer and teachers. The tools and techniques used in online learning can act as a bridge to facilitate communication skill inside and outside the classroom. Social media used in classroom management to present learning materials, lesson plan, class schedule, online practice, feedback, grade summary etc. Social media is widely used for communication between teachers and learners as well as among learners in the form of web-board announcement and online form. Using social media in learning and teaching can motivate the learners to learn by themselves.

Digital Tools for Learning: The Ministry of Human Resources Development (MHRD) introduced various digital initiatives for secondary and higher education during Covid-19 pandemic. Jena (2020) articulates that the online portals for secondary education include diksha, e-Pathshala, National Repository of Open Educational Resources (NROER).

- Diksha -It is an online platform for school education. It has over 80,000 e-content study materials in multiple languages. It includes videos lessons, worksheets, textbooks and assessments.

- E-pathshala - It is a web portal and also in elearning application. It is used by National Council for Education Research and Training. It consist of 696 e-books, 504 flip books, 1886 audios and 2000 videos in different languages for learners from 1st to 12 th.

- National Repository of Open Educational Resources - It is a web portal which has a best quality informational content on diverse topics in multiple languages. It has 14527 files including 401 collections, 2779 documents, 1664 audios, 2586 images and 6153 videos on different languages. Jena (2020). The online portals for higher education are Swayam, Swayam Prabha and e-PG Pathshala.

- Swayam - Swayam is a national online education platform which has 1900 courses for both schools and higher education including engineering, humanities and social science, law and management courses. It has a unique feature that is, it is integrated with the conventional education.

- Swayam Prabha - It has 32 DTH TV channels transmitting educational contents on 24 hours basis. The channels cover both school education and higher education in a wide range of subjects such as engineering, vocational courses, teacher training and social sciences.

- $\quad$ e-PG Pathshala - It is for postgraduate learners. Learners can access to e-PG Pathshala for online courses, e-books and study materials. In e- Pathshala learners can assess the platform without having internet. Jena (2020)

Online Tools and Techniques: The Covid-19 pandemic changes physical classroom to virtual classroom. Virtual classroom is popular all over the world. Teachers can interact with the learners through internet. It provides opportunity to learn from anywhere across the globe and provides a suitable ambience for learning. In physical classroom individual focus is not possible but in virtual classroom, teachers can monitor each and every learner of the class. Activities for enhancing speaking skill in virtual classroom are personal narratives, ted talks, role plays, group discussions, debate and presentations on general and technical topics.

Content Management System: A content management system is a computer software which is used to create and manage digital content. Content management system enables to create a virtual campus where learners can learn, communicate socialize, and access administrative services. The mostly used open source Content Management System platform includes Google sites, h5p, Word press, Square space and Joomla.

Google Sites - Google sites enhance learner digital literacy skills. With the help of google sites teachers can create their own website to include course materials such as videos, images, slides and audio recordings. In google sites teachers can control on whom to access to the pages and who can share materials.

$\mathbf{h} 5 \mathbf{p}$ - The aim of h5p is to develop and share interactive videos, interactive presentations, quizzes, interactive timelines and more. It also allows the learners to test their knowledge and teachers can monitor the learners' engagement and understanding.

Word Press - Word Press is a basic blogging platform and the most popular content management system. It is famous for developing websites and blogs. Learners can develop their writing skill by posting their ideas in the blog.

Square space - Square space is a blogging tool. The main aim of square space was for creating and hosting blogs. Square space allows the users to create their own website. Square space allows the users to edit pages, blog posts and delete posts and pages up to 30 days.

Joomla - Joomla is a free and open source content management system. Joomla includes features such as page caching, RSS feeds, blogs, search and support for language internationalization. It allows the teachers to create, manage and administrate their own courses. 
Learning Management System: Learning management system is a software application. It is used for documentation, administration, reporting, automation, tracking, and delivery of educational courses, training programs and learning programs. Learning management system is specifically designed to create, distribute and manage the delivery of educational content. The learning management system technology enhances learning with faster, productive and cost-effective. Some of the learning management system tools used to connect teacher and learners are google classroom, gnomio, edmodo, schoology.

Google Classroom - The aim of Google Classroom is to simplify creating, distributing and grading assignments. Google Classroom plays an important role in online

teaching- learning process. Some of the features of Google classroom are whiteboard, chat, recording option, participant list, audio and video. The facilities available in Google Classroom are effective for both the learners and teachers.

Gnomio - Gnomio is a free hosting service for Moodle. Moodle is a acronym for Modular Object-Oriented Dynamic Learning Environment. It enables the learners to learn independently at any time without any disturbance and also allows the learners for self-evaluation.

Schoology - The main purpose of Schoology was for sharing notes. It allows the users to create, manage and share academic content. Schoology allows teachers to manage classes by posting daily reminders, direct messages and managing scheduled assignments. Assignments can be in quizzes, forms, links to websites and discussions for learners to share ideas.

Edmodo - Edmodo is a free application and the teachers have to register to create a domain. The learners and teachers need an internet connection to use Edmodo. It allows the teachers to share study materials, conduct quizzes, assignments and communicate with learners, colleagues and parents. Through Edmodo teachers can assign homework, assignments and conduct quizzes for the students. Edmodo makes the learning process effective.

Gamification: The term 'gamification' was coined by Nick Pelling, a British born computer programmer and inventor in 2002. Gamification is the use of game elements in non-game activities. According to Kapp “ gamification is all about using game-based mechanics, aesthetics and game thinking to engage people, motivate action, promote learning and solve problems" (Kapp, 2012). Gamification motivates and encourages learners to achieve their desired learning outcome. Gamification promotes an effective learning environment by increasing problem solving and improves critical thinking. There are many tools for gamification. Some of them are web-based which do not require installation. The most popular gamification tools are socrative, kahoot, flipquiz, duolingo, class dojo, my captain.

Socrative - Socrative is a quiz based, formative assessment tool which enhance teaching and learning. Socrative application allows the teachers to design quizzes, space race, exit tickets and more. Socrative contains different question types such as multiple choices, true or false and short answer. The question order will be changed for each learner. Learners' results for quizzes, quick questions and exit tickets will be shown immediately as soon as they complete the task.

Kahoot - Kahoot is a free online game-based platform for teachers and learners. Kahoot makes learning easy and fun. Kahoot allows the educators to be creative and motivate learners by doing tasks. Kahoot consist of different question types such as quiz, true or false, open-ended and puzzle.

Flip Quiz - Through flip quiz teachers made their classes in an interactive and active way. Some of the features of flip quiz are teachers can create and save boards for future use, the game board in flip quiz will grasp the attention of the learners and it can also be edited.

Duolingo - Duolingo combines various learning methods such as listening to the pronunciation, reading sentences, voice recording, forming phrases by ordering words and matching images to words. Duolingo comprise some gamification elements to motivate and engage learners. It keep the learners interested and less self-conscious of learning. Duolingo can be used by learners of different ages and cultures.

Class Dojo - Class Dojo application changes the learners' classroom into a game based learning which motivates the learners. Some of the basic principles of class dojo are manage classroom behaviour, rewarding and redirecting learners for appropriate and inappropriate behaviors, goal setting and tracking, self-monitoring and self-regulation. Class Dojo application enhances learners behaviour, decreases negative behaviour and goal tracking.

Goal Book: - Goal book is a web-based application. It can be accessed through web-browsers such as firefox, chrome, safari, etc. Goal book is a collaboration platform for teachers, learners and parents which will focus on the achievement of learners learning goal. The main aim of goal book is to track the learning goal of the learner.

My Captain - During the Covid-19 pandemic the growth of My Captain application boosted up. The main aim of this platform is to encourage learners to explore their alternate careers such as comedy, writing, filmmaking, music, production, entrepreneurship, digital marketing, photography, graphic design and more. Gamification makes the entire learning process into a game-based mechanics. The game element used in gamification enhances the teaching and language learning process. Utilizing gamification techniques in e-learning has a positive impact on the learners. 
Data Analysis: The research focuses on the online tools, applications and platforms which enhance the learners' skills in English language teaching during the Covid19 pandemic. A questionnaire was administered to the teachers of English in Government/Aided/Autonomous and Private institutions. The following data analysis represents the predominantly used online tools by the teachers in online teaching.

Select the application frequently used in your online teaching.

\begin{tabular}{l|l|c|c|} 
Table 1 & \multicolumn{2}{|l|}{} \\
\hline kahoot & Flipquiz & Duolingo & h5p \\
\hline 46 & 25 & 14 & 15 \\
\hline
\end{tabular}

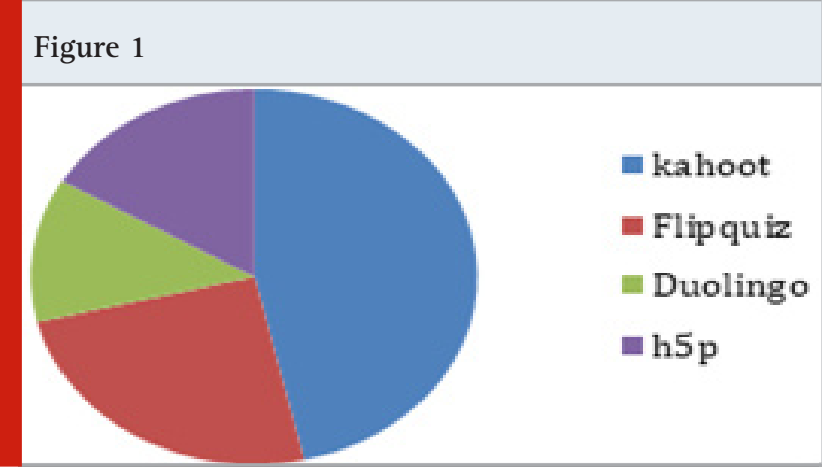

Graph 1 represents that 46\% of the teachers use kahoot in teaching and testing and 25\% of them use flipquiz. Only 14\% of the teachers use duolingo and 15\% of them use $\mathrm{h} 5 \mathrm{p}$.

\section{Select the social media platform frequently used in your teaching.}

\begin{tabular}{|l|c|c|}
\multicolumn{2}{|l|}{ Table 2 } \\
\hline Facebook & Google Meet & Zoom \\
\hline 11 & 49 & 40 \\
\hline
\end{tabular}

Figure 2

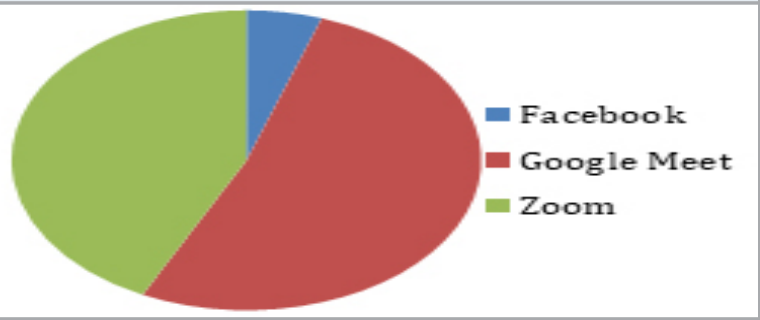

Graph 2 represents that only 11\% of the teachers use facebook while teaching whereas $49 \%$ of them use google meet and $40 \%$ of them use zoom.
Select the online portal frequently used in your teaching.

\begin{tabular}{l|c|c|}
\multicolumn{2}{l}{ Table 3} \\
\hline Swayam & Swayam Prabha & e-PG pathshala \\
\hline 62 & 21 & 17 \\
\hline
\end{tabular}

Figure 3

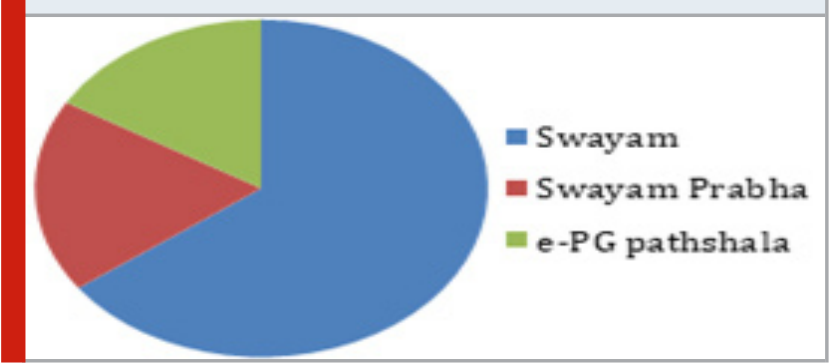

Graph 3 represents that $62 \%$ of the teachers use swayam in their teaching and 21\% of them use swayam prabha. Only $17 \%$ of the teachers use e-PG pathshala in their teaching

\section{Select the learning management system frequently used} in your teaching.

\begin{tabular}{|c|c|c|c|}
\hline Edmodo & Google Classroom & Schoology & Gnomio \\
\hline 27 & 61 & 12 & 0 \\
\hline
\end{tabular}

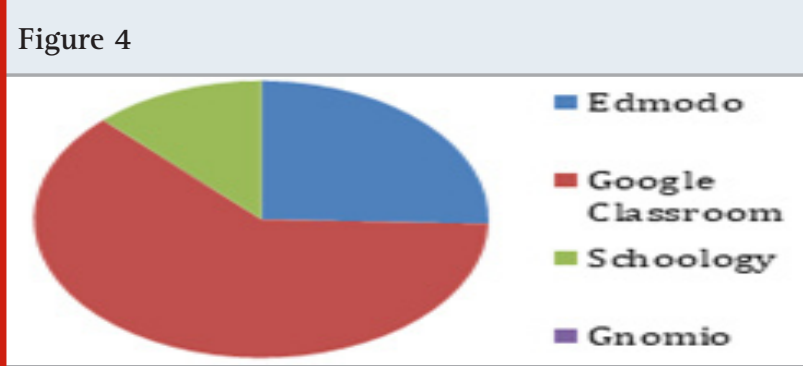

Graph 4 represents that only 27\% of the teachers use edmodo in their teaching and 61\% of the teachers use Google classroom whereas $12 \%$ of them use schoology.

\section{Learners' regularly participate in online classes.}

\begin{tabular}{|c|c|c|c|c|}
\hline Strongly Agree & Agree & Neutral & Disagree & $\begin{array}{l}\text { Strongly } \\
\text { Disagree }\end{array}$ \\
\hline 5 & 37 & 33 & 21 & 4 \\
\hline
\end{tabular}




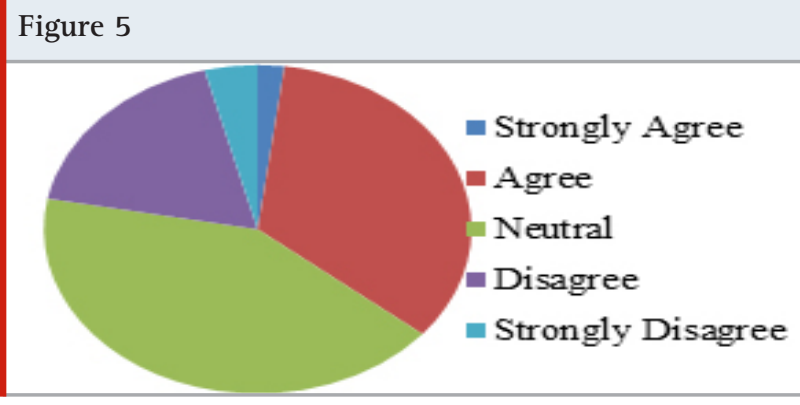

Graph 5 represents that only 5\% of the teachers strongly agree that learners' participation in online class is regular whereas 37\% of the teachers agree and $44 \%$ of them gave a neutral response. 20\% of the teachers disagreed and $4 \%$ of them strongly disagreed to this statement.

The quality of teaching and learning increased through online teaching.

Table 6
\begin{tabular}{l|c|c|c|c|}
\hline $\begin{array}{l}\text { Strongly } \\
\text { Agree }\end{array}$ & Agree & Neutral & Disagree & $\begin{array}{l}\text { Strongly } \\
\text { Disagree }\end{array}$ \\
\hline 6 & 7 & 33 & 44 & 10 \\
\hline
\end{tabular}

\section{Figure 6}

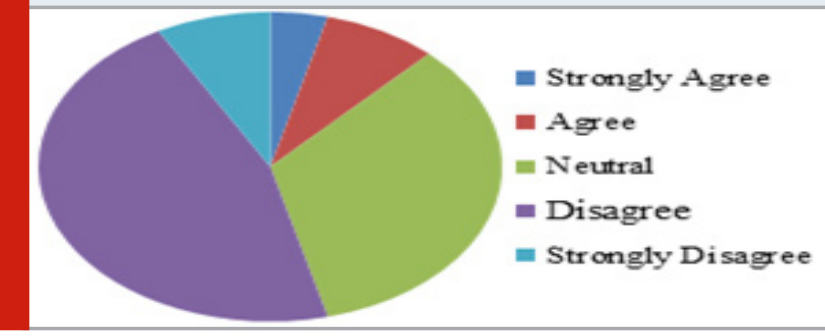

Table 7

\begin{tabular}{|l|c|c|c|c|}
\hline $\begin{array}{l}\text { Strongly } \\
\text { Agree }\end{array}$ & Agree & Neutral & Disagree & $\begin{array}{l}\text { Strongly } \\
\text { Disagree }\end{array}$ \\
\hline 21 & 59 & 20 & 0 & 0 \\
\hline
\end{tabular}

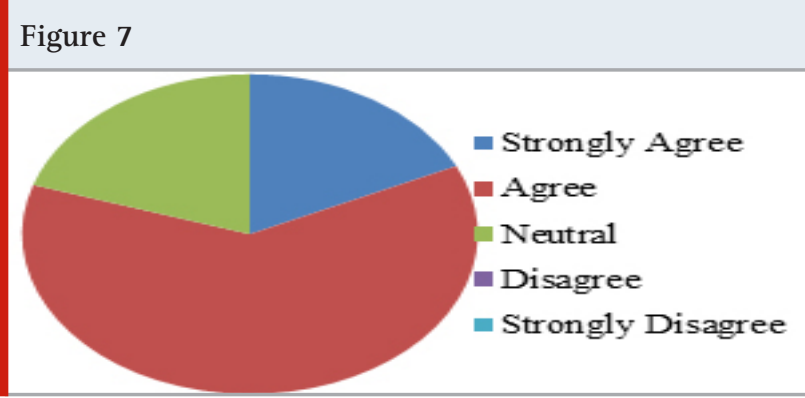

Graph 6 represents that only 6\% of the teachers strongly agree that the quality of the teaching and learning increased through online teaching whereas 7\% of the teachers agree and 33\% of them gave a neutral response.
$44 \%$ of the teachers disagreed and 10\% of them strongly disagreed to this statement.

Teachers and learners' need proper training for online teaching and learning process.

Graph 7 represents that only 21\% of the teachers strongly agree that teachers and learners need proper training for online teaching and learning whereas 59\% of the teachers agree and $20 \%$ of them gave a neutral response.

Using mobile applications to test learners' vocabulary was more interesting and less stressful.

\begin{tabular}{|c|c|c|c|c|}
\hline \multicolumn{5}{|l|}{ Table 8} \\
\hline $\begin{array}{l}\text { Strongly } \\
\text { Agree }\end{array}$ & Agree & Neutral & Disagree & $\begin{array}{l}\text { Strongly } \\
\text { Disagree }\end{array}$ \\
\hline 8 & 36 & 33 & 20 & 3 \\
\hline
\end{tabular}

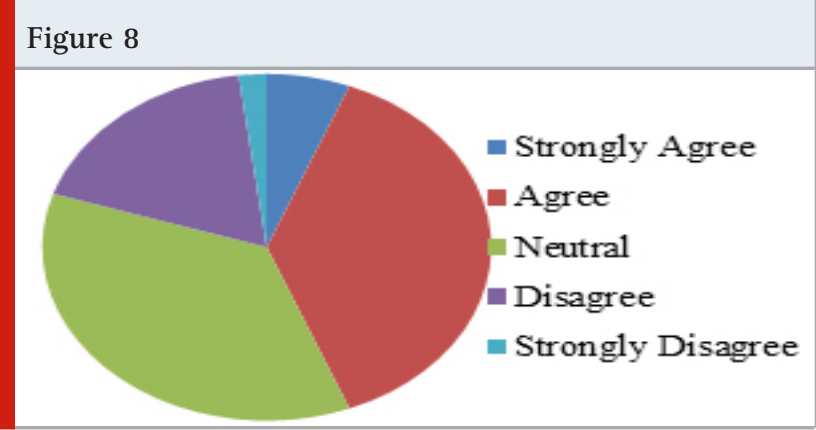

Graph 8 represents that only 8\% of the teachers strongly agree that learners test their vocabulary using mobile application which was interesting and less stressful whereas 36\% of the teachers agree and 33\% of them gave a neutral response. 20\% of the teachers disagreed and $3 \%$ of them strongly disagreed to this statement.

Group discussion in online teaching enhances learners' thinking, listening and speaking skills.

Table 9
\begin{tabular}{l|c|c|c|c|}
\hline $\begin{array}{l}\text { Strongly } \\
\text { Agree }\end{array}$ & Agree & Neutral & Disagree & $\begin{array}{l}\text { Strongly } \\
\text { Disagree }\end{array}$ \\
\hline 6 & 20 & 32 & 30 & 12 \\
\hline
\end{tabular}

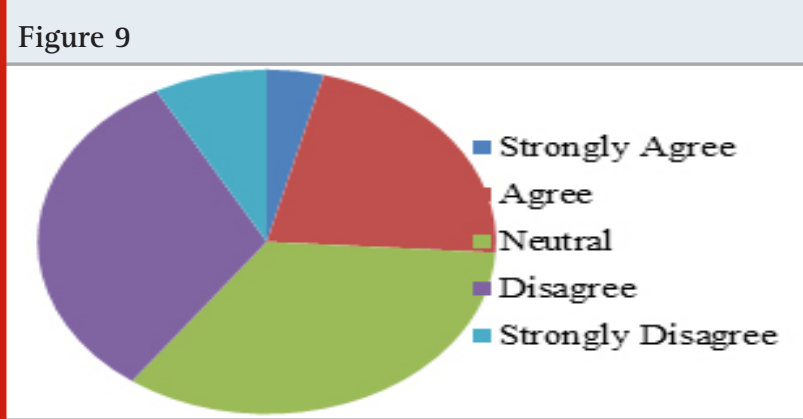


Graph 9 represents that only 6\% of the teachers strongly agree to the statement that learners thinking, listening and speaking skill was enhanced through group discussion in online teaching whereas $20 \%$ of the teachers agree and 32\% of them gave a neutral response. $30 \%$ of the teachers disagreed and $12 \%$ of them strongly disagreed to this statement.

\section{Web-based applications improve learners' listening,} writing and grammar skills.

Table 10

\begin{tabular}{|l|c|c|c|c|}
\hline $\begin{array}{l}\text { Strongly } \\
\text { Agree }\end{array}$ & Agree & Neutral & Disagree & $\begin{array}{l}\text { Strongly } \\
\text { Disagree }\end{array}$ \\
\hline 3 & 45 & 32 & 20 & 0 \\
\hline
\end{tabular}

Figure 10

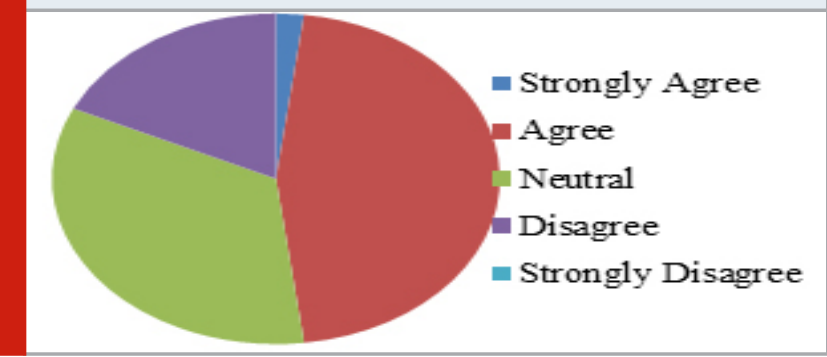

Graph 10 represents that only 3\% of the teachers strongly agree that web-based application improve learners listening, writing and grammar skill whereas $45 \%$ of the teachers agree and 32\% of them gave a neutral response. $20 \%$ of the teachers disagreed.

Government should provide funds to implement online teaching in all spheres of education.

Table 11

\begin{tabular}{|l|c|c|c|c|}
\hline $\begin{array}{l}\text { Strongly } \\
\text { Agree }\end{array}$ & Agree & Neutral & Disagree & $\begin{array}{l}\text { Strongly } \\
\text { Disagree }\end{array}$ \\
\hline 27 & 33 & 23 & 13 & 4 \\
\hline
\end{tabular}

Figure 11

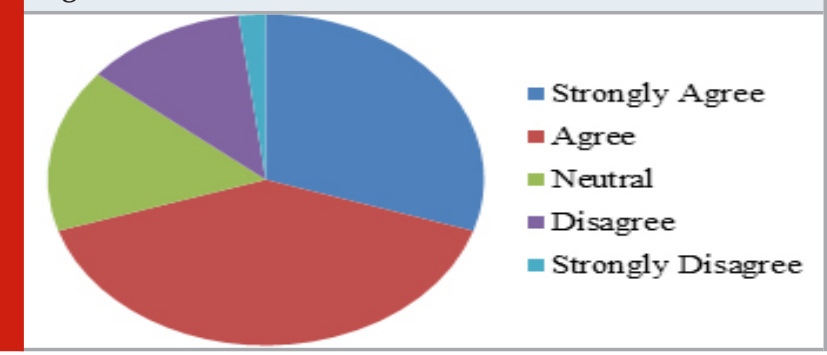

Graph 11 represents that only 27\% of the teachers strongly agree that government should provide funds to implement online teaching whereas 33\% of the teachers agree and 23\% of them gave a neutral response. 13\% of the teachers disagreed and 4\% of them strongly disagreed to this statement.

\section{Findings}

\section{The findings of the study are}

- The spread of Covid-19 and lockdown announced by government made closure of all the educational institutions which affected the education of the learners.

- Online teaching is a solution for the learners to learn during the pandemic. It helped the learners to continue learning without any break.

- $\quad$ Teachers find a positive attitude on online teaching because through online teaching teachers can share the learning materials easily to the learners and new way of teaching is used by the teachers to make the learners learning interesting in the class.

- The learners learn independently without any disturbance in online teaching they can gain more ideas about their subject in internet and can also attend classes at anytime and anywhere they can also save the lecture of the teacher for future reference.

- Various online tools were used by the teachers in online teaching. The online tools help the teachers to interact with the learners, it also improve the learners' interest in learning with fun and less stressful.

- Frequently used online game based application by the teachers is kahoot because it allows the learners to test their skills and makes learning fun.

- The online portal frequently used by teachers is swayam because it offers many courses to the learners with free of cost. Learners can join into the course by verifying the qualification and experience of the teachers.

- Google Meet is a social media platform frequently used by the teachers and learners. It is a common application and group discussions were conducted using google meet with many number of participants.

- The learning management system frequently used by teachers is google classroom. Google classroom enable teachers to create an online classroom and also allows the teachers to post assignments, conduct exams and teachers can alot time limit for the learners to submit their assignments or answer sheet. Late submission of the learners will be marked by google classroom.

- The manual handwritten records were replaced by technology before the pandemic it was done by the teachers.

- Monitoring the learners' attendance and submission of assignment become easy with the help of technology.

- During the pandemic the learners had an opportunity to listen to lectures from everywhere of the world.

- Teachers and learners are able to attend many programs such as webinars, workshops and trainings during this pandemic. The webinars are organized with free of cost or with minimum amount of payment. 
- Learners not only listen to classroom lectures they can also listen to the lectures of many writers, authors and linguist according to their own branch of study.

- Many refresher/orientation programs were arranged for the teachers to get an idea about online teaching and many workshops were organized to educate the teachers about online tools and how to continue the classes in online mode.

- Pandemic has closed the doors of educational institutions but it opened the door for the learners to listen to other lectures. They were not restricted to listen to classroom lectures they were allowed to listen to other lectures.

- Learners were taken to the next level of learning and opened the doors for opportunities of the learners.

\section{Limitations}

The limitations found the researcher are as follows

- All the learners do not get the opportunity to get a mobile phone and laptop with internet connection because of the poor economic status.

- Not all the teachers can handle the online class with effectiveness only few teachers can deliver their lectures effectively.

- Online tools were not used by all the teachers in their teaching.

- Values of the learners and one on one communication are missing in online education.

- Communication is important between teacher and learner but it is missing in online classes.

- Learners do not properly listen to the online classes this leads to lack of classroom management.

- No supervisor's to monitor the learners in examination conducted through online mode.

- Learners were affected psychologically and suffer from few physical ailments such as back pain, eye sight and more.

- Teachers and learners face many psychological challenges such as fear, loss and lack of communication and motivation. Fear plays a dominant role among the teachers and learners during the pandemic.

The study brings out the impact of online teaching among teachers and learners. Online classes boost the language learning of the learners during the pandemic with the help of online tools, applications and platforms. Online tools enhance the skills of the learners and made their learning interesting. Online teaching made the learners to learn without any break and it opened the door to the next level of learning.

\section{CONCLUSION}

The Covid-19 disease pandemic has affected the language learners because all the educational institutions were closed. It had affected the learners over 200 countries in the world. The closure of educational institutions has caused a great disturbance in students learning and teachers teaching. Technology plays a major role in teaching and learning at home during the Covid-
19 pandemic. The pandemic paved a way for online classes. Online classes during pandemic brought various challenges for teachers and learners. Teachers should be innovative in their teaching to make teaching easy. Online classes help the learners to enhance their communication skills.

Technology made learning easy with the help of online tools, applications and platforms which enhance the learners' skills during the Covid-19 pandemic. Various applications used by teachers in online teaching make learning fun and less stressful. Government has also provided several online portals during the pandemic for the development of learning among the learners. Online teaching requires more time for teaching and preparation, teachers use new methods to make the learners attentive in class. Learners can test and improve their skills using mobile applications and web based application. Through online applications teachers can share their learning materials to the learners. Several online applications were frequently used by the teachers and learners because of the features available in the applications which fulfill the needs for their teaching and learning process. Online teaching provides the learners to learn independently and innovative in their learning process.

\section{REFERCENCES}

Al-Mahrooqui Rahma Ibrahim,( 2012) “English Communication skills:How are they taught at schools and universities in Oman?".English Language Teaching. vol.5,no.4.Ap. www.cosenet.org/elt

Dr. R. Abilasha Dr. M. "Ilankumaran, (2018) Developing Communication Skills of Students - An Analysis on Pragmatic Performance" International Journal on Studies in English Language and Literature,vol.7, pp.2631, July

Dr. R. Abilasha Dr. M. Ilankumaran, (2018) English Language Teaching: Challenges and Strategies from the Indian Perspective International Journal of Engineering and Technology, vol.7,no.3.6, pp.202-205, June.

Dr. R. Abilasha, Dr. M. Ilankumaran, (2020 )“A Dynamic Change in The System of Education Owing to The Pandemic Episode - A Study on Post Covid19 Lockdown in Indian Context" The International Journal of Analytical and Experimental Modal Analysis (IJAEMA) UGC CARE listed Journal , vol.XII,NO.VII,July ,pp-170-176

Dr. R. Abilasha, Dr.M.Ilankumaran,( 2019) “Challenges Faced by Teachers in the Classrooms: An Overview on Modern Scenario" International Journal of English Language and Literature in Humanities (IJELLH), vol.7 no.3, Mar, pp.1211-1217

El-Batanouny Maha, Ranya Elkhayat, Hend Elsheikh, (2018) "Using Open-Sources Learning Management System(LMSs) in the Egyptain Undergraduate English as a Foregin Language(EFL) class: A Case Study Addressing Economically Disadvantageed Countries", International Journal of Digital Society.vol.9.no.1.pp.1353-1357.Mar.. www.infonomics society.in 
Gilakjani Abbas Pourhosein, (2016) "The Signification of Listening Comprehension in English Language Teaching" in Theory and Practice in Language Studies. vol.6,no.8,Aug

Hartshorn.K.James,Benjamin.l.McMurry,"The Effect of the Covid-19 pandemic on ESl Learners and TESOL Praactitioners in the United States". International Journal of Tesol Studies. Vol.2.pp.141-156.2020.https:// doi.org/10.4645/ijts.2020.9.11

Jena Pravat Kumar, (2020 ) "Online learning during lockdown period for Covid-19 in India”. International Journal of Multidisciplinary Educational Research. vol.9,issue:5(8),May.www.ijmer.in

Karata Tuce Qzturk, Hulya Tuncer, (2020) "Substaining Language Skills Development of Pre-Service EFL Teachers despite the Covid-19 Interruption: A case of Emergency Distance Education”. Substainability, pp,234, www.mdpi.com

Kiryakova Gabriela, Angelove, Yordanove, "Gamification in Education" www.gamifyingeducation.org

Kumbakonam Usha Rani, (2016 ) "Communication Barriers”. Journal of English Language and Literature. vol.3, pp.74-76.www.joell.in

Li Voyce, (2017 ) "Social media in English Language Teaching and Learning" International Journal of Learning and Teaching, vol.3,no.2,Jun. doi:10.18178/ ijlt.3.2

Low E-Ling, Slyvia Chong, Mary Ellis,( 2014) “Teachers' English communication skills:Using IELTS to measure competence of graduates from a Singaporean teacher education program" Australian Journal of Teacher Education,vol.12,no.10, pp.64.http://ro.ecu.edu.au. Nomass Bassma Basheer, (2013) "The Impact of Using technology in Teaching English as a second language"
English Language and Literature studies.vol,no.1,Feb. www.ccsenet org/ells.

Radha, Mahalakshmi, Sathis Kumar, Saravanakumar, (2020) "E-Learning during Lockdown of Covid-19 Pandemic: A Global Perspective” International Journal of Control and Automation, vol.13,no.4. pp.10881099

Raj Utsav,( 2020) "Indian Education System in Fight against Covid-19 pandemic" International Journal of Creative Research Thoughts(IJCRT), vol.8, issue.7, July. www.ijcrt.org

Rao Parupalli Srinivas, (2019) "The Importance of Speaking Skills in English Clasroom" Alford Council of International English \& Literature Journal.vol.2,no.2 Mar

Rao Parupalli Srinivas, (2019) "The Significance of Writing Skill in ELL Environment" An International Multidisciplinary Research Journal, vol.9, issue.3,March

Senser Burcu, Inci Sagalam Ertem, “Online Teaching Experiences of ELT Instructors”.vol.3,no.3,pp.340-362 .https://Dergipark.org.tr/tr/pub/jetol

Sun Susan Yue Hua, (2011) "Online Language Teaching: the Pedagogical Challenges”. Knowledge Management $\mathrm{Ct}$ E-Learning: A International Journal.vol.3,no.3.pp.428447.

Venkatashiva Reddy B, Arti Gupta,( 2020) "Importance of effective communication during COVID-19 infodemic" Journal of Family Medicine and Primary Care,vol.9, www.jfmpc.com

Woodcock Stuart, Sisco, Eady, (2015) "The Learning Experience: Training Teachers Using Online Synchronous Environments" Journal of Educational Research and Practice, vol.5, issue.1,pp.21-34. 